\title{
Opiates Suppress a Resting Sodium-dependent Inward Current and Activate an Outward Potassium Current in Locus Coeruleus Neurons
}

\author{
Meenakshi Alreja' ${ }^{1}$ and George K. Aghajanian ${ }^{1.2}$ \\ Departments of 'Psychiatry and ${ }^{2}$ Pharmacology, Yale University School of Medicine and the Ribicoff Research Facilities, \\ Connecticut Mental Health Center, New Haven, Connecticut 06508
}

The opioid peptide met-enkephalin (met-ENK) produces an outward current with an increase in input conductance in locus coeruleus (LC) neurons. This current has been attributed to an opening of potassium channels. However, the opioid-induced current tends to reverse at potentials more negative than the expected potassium reversal potential $\left(E_{\mathrm{k}}\right)$ or does not reverse at all. Since lack of reversal can occur if there is a simultaneous increase in one conductance and a decrease in a second conductance, we tested the possible contribution of a second conductance to the opioid-induced outward current in LC neurons. Biochemically, opiates inhibit adenylate cyclase in LC neurons and cAMP-active agents produce a sodium-dependent inward current in these neurons. This current is also present at rest, as sodium substitution hyperpolarizes LC neurons. By inhibiting adenylate cyclase, could opiates be turning off this current? To evaluate this possibility, we used intracellular voltage-clamp technique in rat LC slices, and studied the effect of sodium substitution on the opiate response. Replacement of external sodium ( $80 \%$ ) with Tris or choline caused (1) an outward current with a decrease in input conductance and (2) an $\sim \mathbf{5 0} \%$ decrease in the met-ENK-induced outward current with a shift in its reversal potential toward $E_{\mathrm{k}}$. Extracellular $\mathrm{Ba}^{2+}$, a K+ channel blocker, also partially reduced the opiate response, but it shifted its reversal potential away from $E_{\mathrm{K}}$. The met-ENK-induced outward current was almost totally abolished by combined sodium substitution and extracellular $\mathrm{Ba}^{2+}$ in an additive manner. We conclude that the opiate response in LC neurons tends not to reverse at $E_{k}$ because, in addition to opening $\mathrm{K}+$ channels, opiates simultaneously suppress a resting $\mathrm{Na}^{+}$-dependent inward conductance.

IKey words: opiate, locus coeruleus, noradrenergic, sodium-dependent current, potassium current, intracellular, cAMP]

The action of opiates in the rat locus coeruleus (LC) has been of intercst becausc of its association with major components of opiate tolerance, dependence, and withdrawal (Nestler, 1992). The noradrenergic neurons of the LC possess a high density of $\mu$-opiate-binding sites. Activation of the $\mu$-opiate receptor pro-

\footnotetext{
Received Dec. 11, 1992; accepted Feb. 25, 1993.

We thank Ms N. Margiotta for technical help and Ms L. Fields for help in manuscript preparation.

Correspondence should be addressed to Meenakshi Alreja, Department of Psychiatry, CMHC 306, Yale University School of Mcdicine, 34 Park Street, New Haven, CT 06508.

Copyright @ 1993 Society for Neuroscience $0270-6474 / 93 / 133525-08 \$ 05.00 / 0$
}

duces a membrane hyperpolarization accompanied by an apparent decrease in input resistance in LC neurons (Pepper and Henderson, 1980; Williams et al., 1982). This hyperpolarization has been attributed to the opening of an inwardly rectifying potassium conductance (North and Williams, 1985; Williams et al., 1988) via a pertussis toxin-sensitive G-protein (Aghajanian and Wang, 1986). However, a number of investigators have reported that the opiate response in LC neurons often reverses at potentials much more negative than the potassium equilibrium potential $\left(E_{\mathrm{K}}\right)$ (Aghajanian and Wang, 1986; Williams et al., 1988; Chiu et al., 1990). The extremely negative reversal potentials or even lack of reversal could result from the opioids acting at predominately electrotonically distant parts of the voltage-clamped cell (Williams et al., 1988) and/or if there was a simultaneous increase in one conductance and a decrease in a second conductance. Theoretically, when a current results from conductance changes of opposite signs, its reversal potential can lie outside the limit of the Nernst potential of each of the participating ions (Brown et al., 1971). It has been suggested previously that in addition to opening potassium channels, opiates might also suppress a cAMP-dependent inward current that is present at rest in LC neurons and is voltage independent between -60 and $-120 \mathrm{mV}$ (Aghajanian and Wang, 1987; Wang and Aghajanian, 1987). The biochemical basis for such a suppression derives from the fact that opiate receptors, through their coupling with the inhibitory $G$-protein, $G_{i}$, inhibit adenylate cyclase in various regions of the brain including the $\mathrm{LC}$ (Duman et al., 1988). The cAMP-induced inward current in LC neurons is carried at least in part by sodium, as it is markedly reduced in low-sodium artificial cerebrospinal fluid (ACSF), but it is insensitive to TTX.

Accordingly, in the present study we investigated the possible contribution of a sodium-dependent conductance to the net opiate-induced outward current in LC neurons. We tested the effect on the opiate response of replacing sodium in the ACSF with choline chloride (choline) or Tris- $\mathrm{HCl}$ (Tris). In addition we reexamined the effect of external $\mathrm{Ba}^{2+}$, a potassium channel blocker, on the opiate response.

\section{Materials and Methods}

LC slices $(500 \mu \mathrm{m})$ were prepared as previously described (Aghajanian and Rasmussen, 1989). The slices were incubated at $33 \pm 0.5^{\circ} \mathrm{C}$ in an interface chamber continuously perfused with ACSF at a rate of $\sim 1 \mathrm{ml}$ min. The ACSF ( $\mathrm{pH} 7.35-7.38$ ), equilibrated with $95 \% \mathrm{O}_{2}-5 \% \mathrm{CO}_{2}$, contained (in mM) NaCl, 126; $\mathrm{KCl}, 5 ; \mathrm{NaH}_{2} \mathrm{PO}_{4}, 1.25 ;$ D-glucose, 10; $\mathrm{NaHCO}_{3}, 27 ; \mathrm{CaCl}_{2}, 2$; and $\mathrm{MgSO}_{4}, 2$. The LCs were visually identified in rat brainstem slices as dark oval areas in the upper pons on the lateral borders of the central gray and the fourth ventricle, at a frontal plane at or just anterior to the genu of the facial nerve. 
A

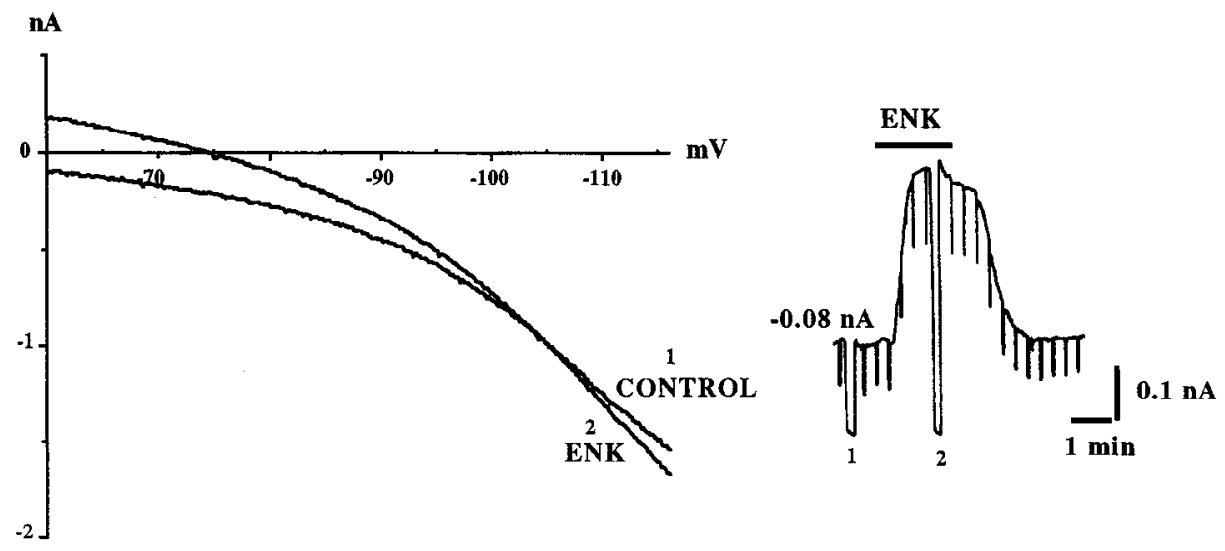

Figure 1. Effect of met-ENK (ENK) on passive properties of LC neurons. $A$, In an LC neuron voltage clamped at $-60 \mathrm{mV}$ (holding current, $-0.08 \mathrm{nA}$ ), bath application of met-ENK $(200 \mu \mathrm{M})$ produced a $330 \mathrm{pA}$ outward current with an increase in apparent input conductance as indicated by an increased current deflection in response to a constant voltage step $(-10 \mathrm{mV})$. The current reversed at $-105 \mathrm{mV}$ in relation to the control ramp. $B$, In another cell, metENK produced a $320 \mathrm{pA}$ outward current that did not reverse in the voltage range tested $(-60$ to $-120 \mathrm{mV})$. Such nonreversing, near-parallel $I-V$ plots were obtained in $52 \%$ of the LC neurons tested. Input conductance was measured by stepping the membrane potential to $-70 \mathrm{mV}$ for $1.2 \mathrm{sec}$ every 20 sec.
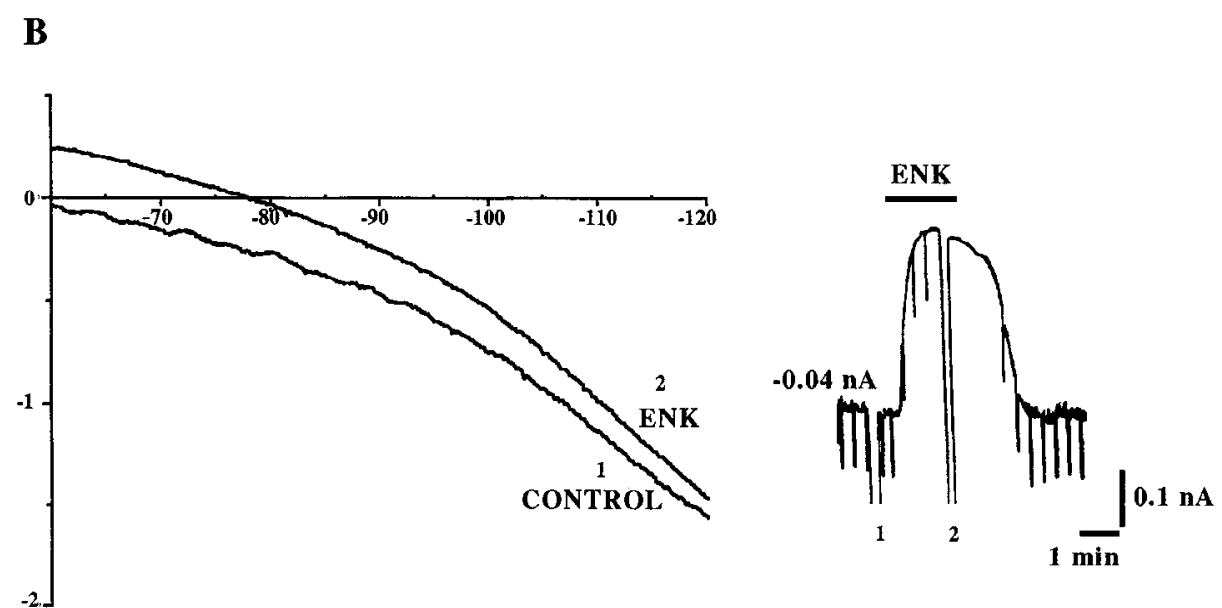

Intracellular recordings wcre made from LC ncurons using sharp microelectrodes filled with $2 \mathrm{M} \mathrm{KCl} \mathrm{(25-35} \mathrm{M} \Omega$ ). Single-electrode voltageclamp recordings were made using an Axoclamp-2A amplifier. Noradrenergic neurons in the LC were identified by their spontaneous firing, their characteristic long-duration action potentials $(\sim 2 \mathrm{msec})$, their large afterhyperpolarizations, and their high input resistances $(60-200 \mathrm{M} \Omega)$. The cells selected for study had spike amplitudes of $80-100 \mathrm{mV}$ and spontaneous firing rates below 4 spikes/sec. All experiments were done under voltage clamp, using the discontinuous single-electrode voltageclamp mode. The headstage output was continuously monitored to ensure adequate electrode settling time. Settling times were within 50$75 \mu \mathrm{sec}$, allowing switching frequencies of 4-6 kHz and a loop gain of $10 \mathrm{nA} / \mathrm{mV}$ (30\% duty cycle). Although phase lag was used to prevent oscillations, false clamping was avoided by using optimal capacitance neutralization and by selecting a switching frequency that allowed full settling of the input voltage to a horizontal baseline. The cells were voltage-clamped at -60 or $-65 \mathrm{mV}$. The input impedance of each cell was continually monitored by stepping the membrane potential to -65 or $-70 \mathrm{mV}$ for $1.2 \mathrm{sec}$ at 20 -sec intervals. Data were continuously recorded on a strip chart recorder (Gould 2200). Current-voltage plots ( $I-V$ curves) were obtained before and after opiate application under different experimental conditions using slow ramps $(2-6 \mathrm{mV} / \mathrm{sec})$ to allow for attainment of steady state conditions. The ramps were generated using pClamp software (Axon Instruments) on an IBM-AT clone. The currents were filtered at $10 \mathrm{~Hz}$ on an in-line 8-pole Bessel filter. Acquired data were transferred to a Macintosh IIsi, and the $I-V$ curves were plotted using Axograph software (Axon Instruments).

The effect of the various interventions on the opiate response was studied in the same cell; thus, each cell served as its own control. All statistical comparisons were made using the Student's paired $t$ test and all values are expressed as mean \pm SEM.
The opioid peptide [met $\mathrm{m}^{5}$-enkephalin (met-ENK; 100-200 $\mu \mathrm{M}$ ) was used to produce the opiate response by bath application. Sodium substitution in the ACSF was carried out by replacing $80 \%$ of the $\mathrm{NaCl}$ equiosmolarly with either choline chloride or trizma hydrochloride/base (Tris). To block muscarinic responses, atropine $(5 \mu \mathrm{M})$ was added to all solutions containing choline. $\mathrm{BaCl}_{2}(100-200 \mu \mathrm{M})$ was added to the ACSF. All reagents were obtained from Sigma or Mallinckrodt and all drugs were bath applied by turning a three-way valve that switched from ACSF to the test solution.

\section{Results}

Bath application of met-ENK (100-200 $\mu \mathrm{M})$ produced an outward current in LC neurons (amplitude, $243.6 \pm 11.8 \mathrm{pA} ; n=$ 44) with an increase in apparent input conductance. The reversal potential of the response was ascertained by applying slow hyperpolarizing ramps from a holding potential of -60 or -65 $\mathrm{mV}$. In 21 of the 44 neurons tested, the outward current reversed within the voltage range tested (Fig. $1 A ;-60 \mathrm{mV}$ from holding potential) with a mean reversal of $-108 \pm 2.4 \mathrm{mV}$ in $5 \mathrm{~mm}$ external potassium $\left(\left[\mathrm{K}^{+}\right]_{o}\right)$. In the remaining neurons the opioid current did not reverse in the voltage range tested (Fig. $1 \mathrm{~B}$ ). The mean reversal potential for the 44 neurons was $-119.71 \pm 2$ $\mathrm{mV}$ (an arbitrary reversal potential of $130 \mathrm{mV}$ was assigncd to cells in which the opiate response did not reverse by -120 $\mathrm{mV}$ ). By the Nernst equation, the expected reversal potential was $-88 \mathrm{mV}$ under our experimental conditions $\left(\left[\mathrm{K}^{+}\right]_{o}=5 \mathrm{mM}\right.$, $33^{\circ} \mathrm{C}$ ), assuming an internal $\mathrm{K}^{+}$concentration of $140 \mathrm{~mm}$. An 


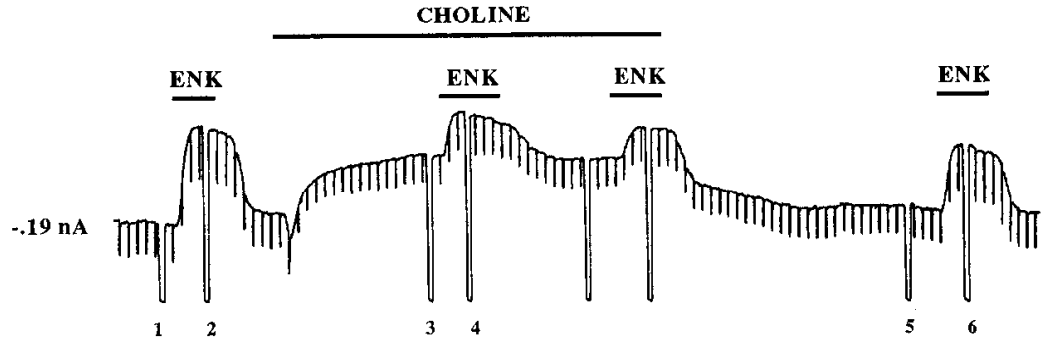

B

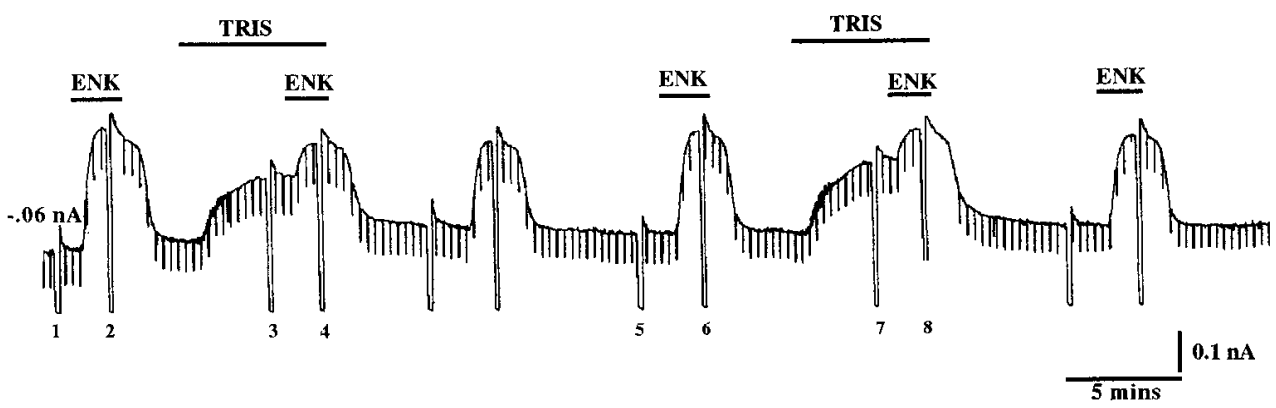

Figure 2. Effect of sodium substitution with choline or Tris on the membrane properties and the opiate response of an LC neuron. $A$, Effect of replacing $80 \%$ of the sodium in the ACSF with choline chloride. In an LC neuron voltage-clamped at $-65 \mathrm{mV}$, met-ENK (100 $\mu \mathrm{M}$ ) produced a $230 \mathrm{pA}$ outward current. Eighty percent sodium substitution with choline chloride produced a transient inward current followed by a sustained outward current. The transient inward current was probably due to activation of nicotinic receptors; the muscarinic response to choline was blocked by addition of $5 \mu \mathrm{M}$ atropine sulfate. The $130 \mathrm{pA}$ persistent outward current was accompanied by a small decrease in input conductance, suggesting reduction in a resting sodium conductance. Following sodium substitution, met-ENK produced only a 100 pA response. On washout of choline the opiate response returned toward control values. Input conductance was measured by stepping the membrane potential to $-75 \mathrm{mV}$. $1-6$ indicate the time points at which $I-V$ curves were obtained and correspond to examples shown in Figure 3 . $B$, Effect of extracellular sodium substitution with Tris on passive membrane properties of an LC neuron and its opiate response. This cell was voltage-clamped at $-60 \mathrm{mV}$. Met-ENK produced a $320 \mathrm{pA}$ outward current in this cell, which did not reverse in the voltage range tested (see Fig. 4). Substitution of Na+-ACSF with Tris-ACSF produced a persistent outward current of $170 \mathrm{pA}$ and a decrement in the magnitude of the met-ENK-induced outward current (130 pA) with a simultaneous shift in the reversal potential toward the $\mathrm{K}^{+}$reversal potential (Fig. 4). All these effects were reversible on washout, and a second $\mathrm{Na}^{+}$substitution with Tris produced similar changes. $1-8$ indicate the time points at which $I-V$ curves were obtained and correspond to examples shown in Figure 4. Input conductance was measured by stepping the membrane potential to $-65 \operatorname{mil}$.

$E_{\mathrm{K}}$ of $-88 \mathrm{mV}$ seems a likely estimate, as the slow spike afterhyperpolarization also reversed between -85 and $-90 \mathrm{mV}$ in these cells (as measured by the analysis of tail currents, not shown; $n=5$ ). This value agrees with previous current-clamp studies in the LC (Andrade and Aghajanian, 1984).

The inability of the opiate response to reverse at $E_{\mathrm{K}}$ could be due to its action at electrotonically distant parts of the LC neuron or because the opiates may produce a simultaneous increase and decrease in conductance (Brown et al., 1971). It has previously been suggested that opiates might suppress a second conductance in LC neurons-a cAMP-induced inward current (Aghajanian and Wang, 1987). Since the cAMP current is sodium dependent (Wang and Aghajanian, 1987), we studied the effect of sodium substitution on the opiate-induced outward current in $\mathrm{LC}$ neurons.

\section{Effect of sodium substitution}

The effect of substituting $80 \%$ of the $\mathrm{NaCl}$ in the ACSF with choline chloride or Tris was studied in $11 \mathrm{LC}$ neurons. Sodium substitution with choline produced a transient inward current followed by a persistent outward current (Fig. $2 A$ ) in all seven neurons tested. The transient inward current was likely due to the effect of choline on nicotinic receptors since the nicotinic response desensitizes within $2 \mathrm{~min}$ in LC neurons (Egan and North, 1986); muscarinic effects of choline were blocked by including $5 \mu \mathrm{M}$ atropine in choline-ACSF. One hundred percent substitution of $\mathrm{Na}^{+}$in the ACSF with choline also produced a transient inward current followed by an outward current. However, $100 \% \mathrm{Na}^{+}$substitution also produced a more delayed (3$5 \mathrm{~min}$ ) inward current with an increase in input conductance. This inward current may be secondary to impairment in ambient excitatory amino acid uptake at very low levels of sodium, as has been reported in hippocampal slices (Parsons et al., 1992). Therefore, we replaced only $80 \%$ of the $\mathrm{Na}^{+}$in our experiments. The persistent outward current following $80 \% \mathrm{Na}^{+}$substitution with choline had an amplitude of $144.3 \pm 18.5 \mathrm{pA}$ at $-60 \mathrm{mV}$; ( $n=7$; range, $100-250 \mathrm{pA}$ ). It was accompanied by a $15.7 \pm$ $2.2 \%$ decrease in input conductance (before choline, $10.5 \pm 0.8$ $\mathrm{nS}$; after choline, $8.9 \pm 2.3 \mathrm{nS}$ as measured between -60 to $-70 \mathrm{mV} ; p<0.001$, paired $t$ test). This suggested that LC ncurons posscss an inward current near resting potentials that is carried in large part by sodium.

In addition to producing a persistent outward current, sodium substitution by choline produced a $54.8 \pm 4.1 \%$ decrease in the met-ENK-induced outward current (Fig. 2A; see also Fig. 7; before choline, $242.9 \pm 84.4 \mathrm{pA}$; after choline, $104.3 \pm 18.8$ $\mathrm{pA} ; n=7 ; p<0.001$, paired $t$ test). This could be explained if about $50 \%$ of the opiate current at $-60 \mathrm{mV}$ results from blockade of an inward current that is carried in part by sodium ions. The decrement in the opiate response was also accompanied by a shift in the reversal potential of the opiate response (Fig. 3). In six of seven neurons the reversal potential of the opiate response shifted to less negative values and closely approached $E_{\mathrm{K}}$, indicating that this remaining current was carried chiefly 

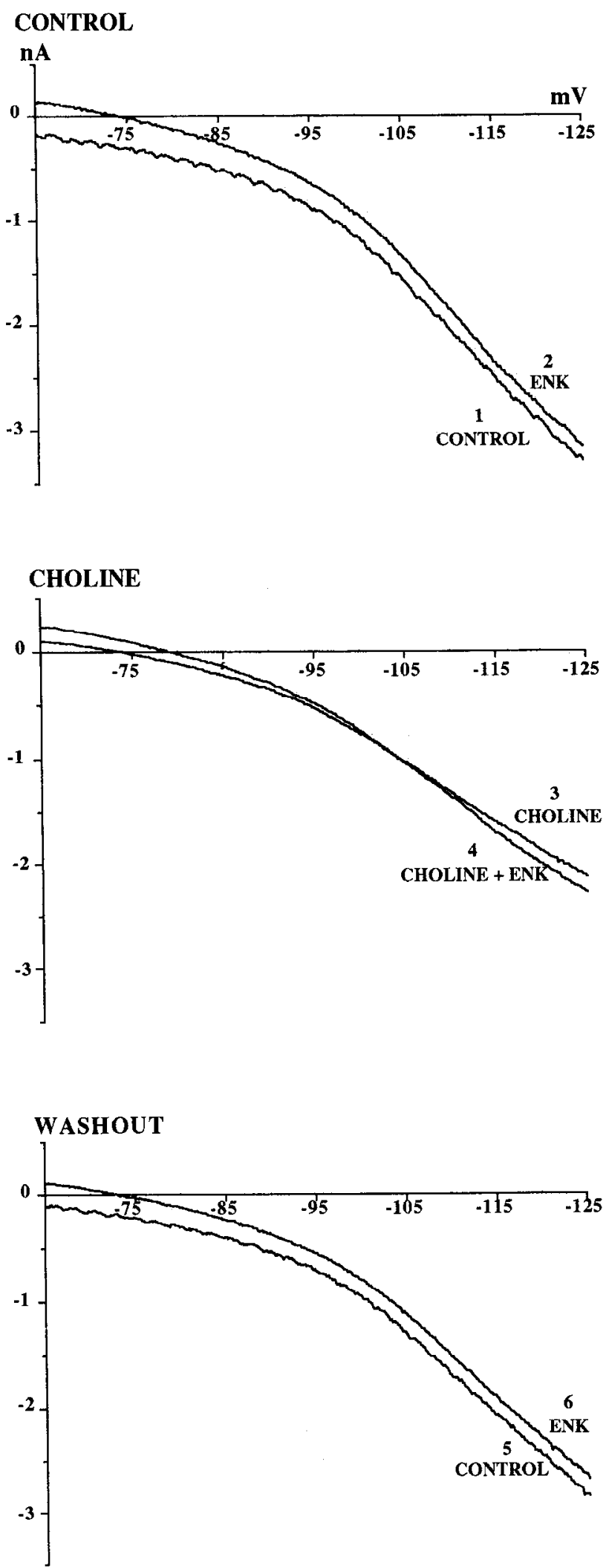

Figure 3. Effect of sodium-substituted ACSF (with choline chloride) on the reversal potential of the opiate response (same cell as Fig. $2 A$ ). Under control conditions $\left(\mathrm{Na}^{+}-\mathrm{ACSF}\right)$ nearly parallel $I-V$ curves were obtained following met-ENK application in an LC neuron voltageclamped at $-65 \mathrm{mV}$ (top). Following application of choline, the reversal potential of the opiate response shifted toward $E_{\mathrm{K}}$ (middle). Note that sodium substitution also produced an outward current and decreased the magnitude of the opiate response. Following washout of choline the opiate response returned toward control values (bottom). by potassium ions. Choline substitution did not have any apparent effect on the inward rectifying properties of the LC neurons or on the reversal potential of the spike afterhyperpolarization ( $n=2$, not shown). All cffects of choline (i.e., on the holding current, the magnitude of the opiate-induced outward current, and the shift in its reversal potential) reversed on switching back to regular ACSF containing $\mathrm{Na}^{+}$.

Sodium substitution with Tris also produced a persistent outward current accompanied by an apparent decrease in input conductance (Fig. $2 B$ ) in the four neurons tested (mean current amplitude, $136 \pm 25.6 \mathrm{pA}$ ). However, unlike choline, Tris did not produce a transient inward current, probably since it does not activate nicotinic cholinergic receptors. As illustrated in Figure $2 B$ (see also Fig. 7), sodium substitution with Tris also produced a decrement $(57.5 \pm 2.0 \%)$ in the magnitude of the opiate response (before Tris, $242.5 \pm 37.5 \mathrm{pA}$; after Tris, 102.5 $\pm 15.5 \mathrm{pA} ; n=4 ; p<0.01$ paired $t$ test) and a shift in the reversal potential of the opiate response to positive values closer to the potassium reversal potential (Fig. 4); all effects were reversiblc and reproducible in the samc cell (Figs. 2, 4). These experiments suggested that the met-ENK-induced outward current in LC neurons is carried primarily by potassium only when there is suppression of a resting $\mathrm{Na}^{+}$-dependent conductance.

\section{Effect of external barium on the opiate response}

Since blockade of the resting sodium-dependent component of the opiate-induced outward current shifted the reversal potential toward $E_{\mathrm{K}}$, blockade of $\mathrm{K}^{+}$channels should shift the opiate reversal potential away from $E_{\mathrm{K}}$. To test this possibility, we studied the effect of extracellular $\mathrm{Ba}^{2+}$ on the opiate response. In agreement with previous studies, bath application of $100 \mu \mathrm{M}$ $\mathrm{BaCl}_{2}$ produced an inward current associated with a decrease in apparent input conductance in all $11 \mathrm{LC}$ neurons tested. It also blocked inward rectification in all the cells tested, as has been reported previously (Williams et al., 1984, 1988; Osmanovic and Shefncr, 1987). In addition, it reduccd the amplitude of the opiate response (Fig. $5 A$ ) by $39.5 \pm 5.2 \%$ (see Fig. $7 ; n$ $=7 ; p<0.001$ ) in ACSF containing $5 \mathrm{mM} \mathrm{K}^{+}$(before, 242.2 $\pm 28.5 \mathrm{pA}$; after, $146.7 \pm 14.1 \mathrm{pA} ; n=9$ ). External barium also produced a negative shift in the reversal potential of the opiate response. In three cells, the opiate response reversed at $-100.7 \pm 1.7 \mathrm{mV}$ under control conditions, and following application of $\mathrm{Ba}^{2+}$ the opiate response no longer reversed in the voltage range tested $(-60$ to $-120 \mathrm{mV})$ and, by extrapolation, shifted to more negative potentials (Fig. $5 B$ ). In another three neurons the opiate response did not reverse in the voltage range tested either before or after the application of barium. Thus, the reversal potential of the opiate response did not shift to a less negative value in any cell following the application of $\mathrm{Ba}^{2+}$. This suggested that the opiate response remaining after $\mathrm{Ba}^{2+}$ is primarily due to the effect of met-ENK on a second conductance, which is fairly voltage independent between -60 and -120 $\mathrm{mV}$.

\section{Combined effect of sodium substitution and extracellular $\mathrm{Ba}^{2+}$ on the opiate response}

Sodium substitution or $\mathrm{BaCl}_{2}$ independently reduced the magnitude of the opiate current to about $40-50 \%$ of the control values. However, these two treatments shifted the reversal potential of the opiate response in opposite directions, suggesting different underlying mechanisms. To determine whether sodium substitution and external $\mathrm{Ba}^{2+}$ were indeed reducing the am- 
$\mathbf{A}$

\section{nA}

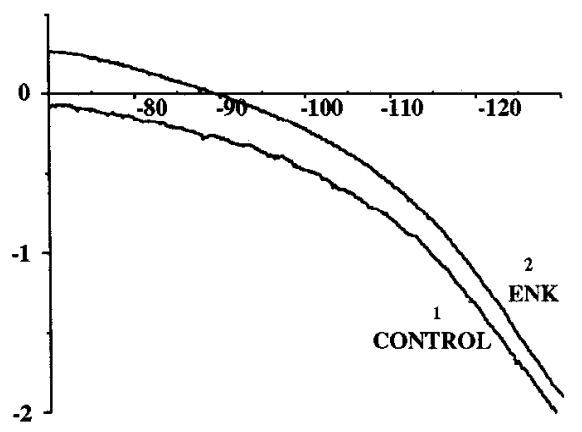

C

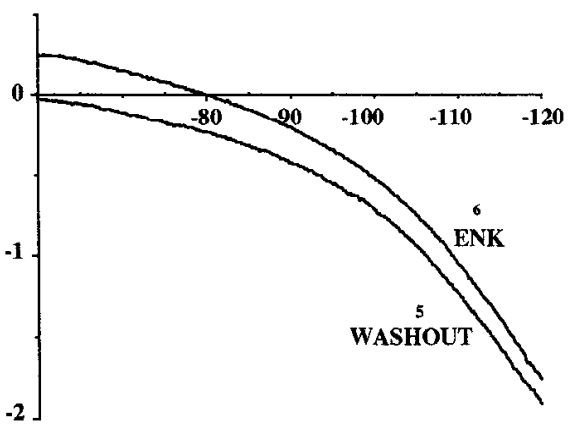

B

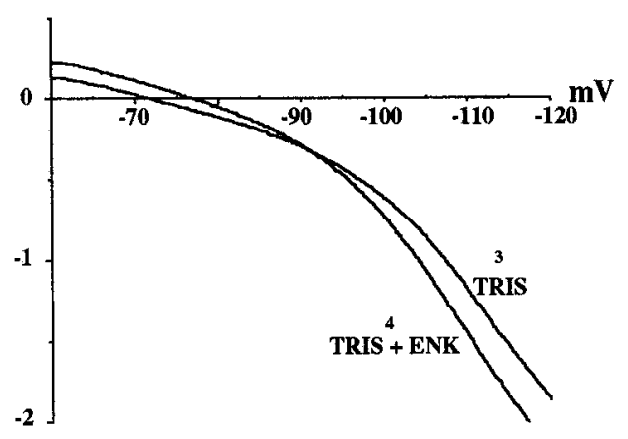

D

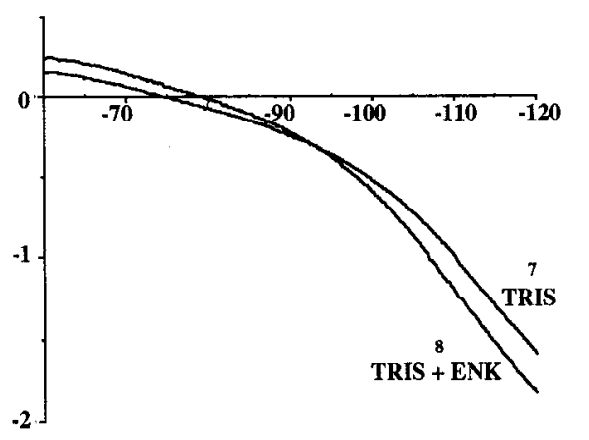

Figure 4. Effect of sodium substitution with Tris on the reversal potential of the opiate response (same cell as Fig. $2 B) . A, I$ and 2 are $I-V$ curves obtained before and after met-ENK under control conditions in $\mathrm{Na}^{+}-\mathrm{ACSF}$; the metENK-induced current did not reverse in the voltage range tested. $B$, Following replacement of $\mathrm{Na}^{+}$-ACSF with TrisACSF, the holding current shifted to positive values, the opiate-induced current decreased in magnitude, and the remaining opiate current reversed at $-92 \mathrm{mV}$. $C$, On resubstitution of $\mathrm{Na}^{+}-$ ACSF, the holding current, the opiate response, and its reversal potential returned to control values. $D$ shows that the effects of $\mathrm{Na}^{+}$substitution on the opiate response were reproducible in the same cell.

$\mathbf{A}$
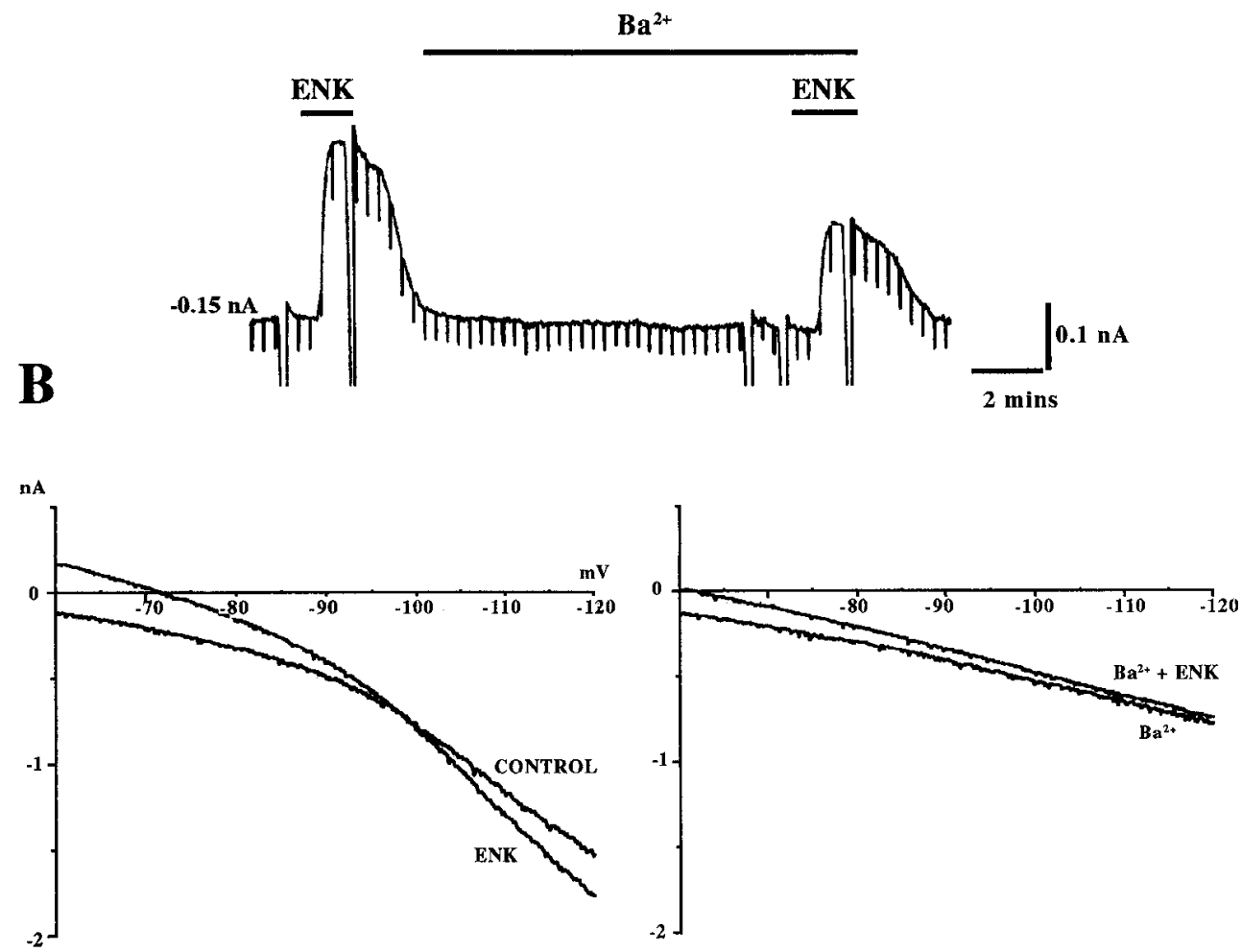

Figure 5. Effect of extracellular barium on the amplitude of the met-ENKinduced outward current in an LC neuron. $A$, Met-ENK (200 $\mu \mathrm{M})$ produced a 320 pA current. $\mathrm{BaCl}_{2}(200 \mu \mathrm{M})$ applied for $10 \mathrm{~min}$ produced a $20 \mathrm{pA}$ inward current with an apparent decrease in input conductance. Following application of $\mathrm{Ba}^{2+}$, met-ENK produced a 190 pA outward current $(40.6 \%$ of the control response). This experiment was done in $2.5 \mathrm{~mm}$ external potassium. The high-amplitude excursions from the holding current mark the time points at which ramps were applied to obtain $I-V$ curves. Input conductance was measured by stepping the membrane potential to $-70 \mathrm{mV}$. $B$, Effect of extracellular barium on the reversal potential of the met-ENK-induced outward current in an LC neuron. A reversal potential of $-98 \mathrm{mV}$ was recorded under control conditions in an LC neuron (left). Following application of $\mathrm{BaCl}_{2}$ $(200 \mu \mathrm{M})$ the inward rectification was lost and the opiate response did not show reversal down to $-120 \mathrm{mV}$ (right). Also note the lower magnitude of the opiate response following application of barium. This experiment was done in $5 \mathrm{~mm}$ external potassium. 


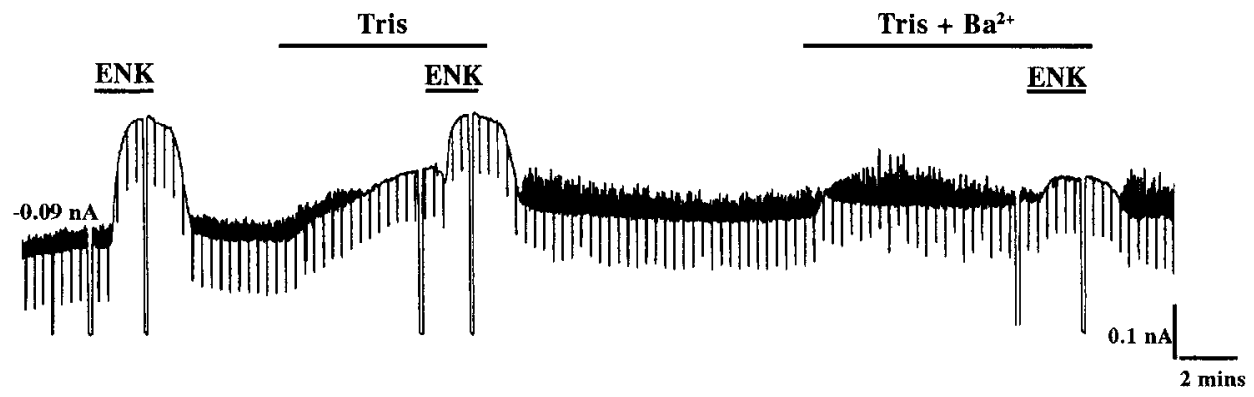

Figure 6. Effect of combined application of Tris-ACSF and external barium on the opiate response in an LC neuron. In this cell, voltage-clamped at $-60 \mathrm{mV}$, met-ENK $(200 \mu \mathrm{M})$ produced a $250 \mathrm{pA}$ outward current that did not reverse to $-120 \mathrm{mV}$ (not shown). Replacement of Na ${ }^{+}$-ACSF with Tris-ACSF produced a $130 \mathrm{pA}$ outward current with a decrease in input conductance, and a subsequent application of met-ENK produced a $120 \mathrm{pA}$ current that reversed at $-90 \mathrm{mV}$ (not shown). Tris-ACSF containing $200 \mu \mathrm{M} \mathrm{BaCl} \mathrm{B}_{2}$ produced a smaller outward current (because of an opposing $\mathrm{Ba}^{2+}$-induced inward current) but a much larger reduction in the met-ENK-induced outward current (40 pA). Note that met-ENK suppressed spontaneous membrane current oscillations despite the marked reduction in outward current. All input conductance measurements were made by stepping the membrane potential to $-70 \mathrm{mV}$.

plitude of the opiate response via different mechanisms, we studied the combined effect of the two treatments on the opiate response. The opiate response was almost totally abolished following combined $\mathrm{Na}^{+}$substitution and external $\mathrm{Ba}^{2+}$. Eighty percent sodium substitution with choline combined with external $\mathrm{Ba}^{2+}$ reduced the amplitude of the opiate current to $83.5 \pm$ $2.7 \%$ of the control values $(n=2$; Figs. 6,7$)$. Similarly, $\mathrm{Na}^{+}$ substitution with Tris together with external $\mathrm{Ba}^{2+}$ produced a $78.6 \pm 2.9 \%$ reduction in the magnitude of the opiate response $(n=5 ; p<0.01)$. Figure 6 illustrates the effect of the combined treatment on a cell. $\mathrm{Na}^{+}$substitution with Tris produced an outward current and a $52 \%$ reduction in the opiate response. A subsequent combined application of Tris and $\mathrm{Ba}^{2+}$ produced a smaller outward current than did Tris alone (due to an incomplete recovery from the first application of Tris and to an opposing inward current that is induced by $\mathrm{Ba}^{2+}$ ). Under these

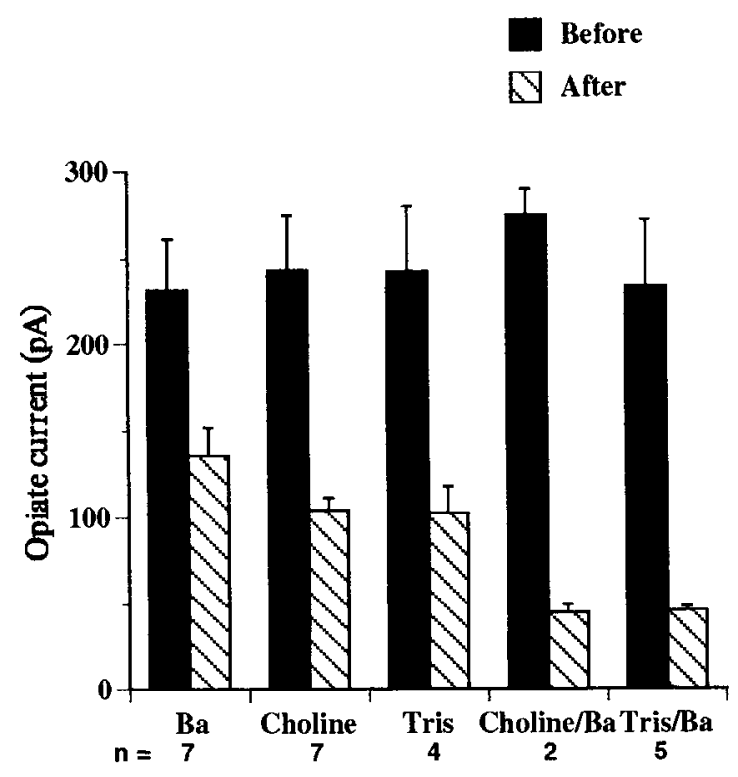

Figure 7. Summary of the effects of various treatments on the amplitude of the met-ENK-induced outward current in LC neurons. Note that external $\mathrm{Ba}^{2+}$ and sodium substitution (with choline or Tris) independently produced a $40-60 \%$ decrement in the opiate response. The effect of both treatments was additive, as following combined treatment with $\mathrm{Na}^{+}$-substituted ACSF and external $\mathrm{Ba}^{2+}$, the opiate current was almost completely abolished. conditions, the opiate response was almost totally abolished. Thus, sodium substitution and external $\mathrm{Ba}^{2+}$ reduced the magnitude of the opiate response in LC neurons in an additive manner.

\section{Discussion}

The results of this study indicate that the opiate-induced outward current in LC neurons has two components, the first arising from the activation of an outward potassium current and the second resulting from the turning off of a sodium-dependent inward current. The outward potassium current has been extensively described in numerous previous studies (e.g., Pepper and Henderson, 1980; North and Williams, 1985; Williams et al., 1988). However, the involvement of an additional conductance has not been demonstrated previously. The relative contribution of these two components was estimated by substitution experiments in which $80 \%$ of the sodium in the ACSF was replaced with two pharmacologically distinct compounds, choline or Tris, keeping the chloride constant. Sodium substitution by itself resulted in an outward current $(\sim 140 \mathrm{pA})$ associated with a significant decrease in input conductance; this outward current was approximately half of the outward current induced by met-ENK in the same cells. Development of an outward current following sodium substitution is not a general phenomenon (e.g., in mouse spinal sensory ganglion neurons, sodium substitution with Tris or choline produces minimal changes in the holding current at -50 to $-60 \mathrm{mV}$; Mayer and Westbrook, 1983). Following sodium substitution in LC neurons, met-ENK induced an outward current that was also approximately half of the original met-ENK current. Thus, the sum of the two outward currents approximated the full opiate-induced current that occurs in the presence of normal concentrations of sodium.

Another indication of the existence of two components of the opiate-induced outward current in LC neurons is the fact that the reversal of the current, as seen in slow-ramp $I-V$ curves, is often substantially negative to the theoretical potassium reversal potential. This apparent negative shift in the reversal potential of the opiate current in LC neurons has been reported previously by several investigators (Aghajanian and Wang, 1986; Williams and Marshall, 1987; Williams et al., 1988; Chiu et al., 1990) and has been confirmed in the present study. The extremely negative reversal potentials (or the lack of reversal) has been attributed to actions of opiates on electrotonically distant parts of the voltage-clamped cell (Williams et al., 1988), to the ex- 
istence of electrical coupling in younger animals (Williams and Marshall, 1987), or to the presence of an additional conductance (Aghajanian and Wang, 1986; Chiu et al., 1990). If the opioid current resulted from a simultaneous increase in one conductance and a decrease in a second conductance, the failure to obtain reversals in the expected range could be explained (Brown et al., 1971). Also, the presence of an opiate-induced outward current at $E_{\mathrm{K}}$ can be explained if opiates suppress a resting sodium-dependent inward current in addition to opening potassium channels. In the present study, the opiate response reversed between -95 and $-120 \mathrm{mV}$ in $52 \%$ of the neurons tested. The mean reversal potential in these $52 \%$ neurons was -108 $\pm 2.4 \mathrm{mV}$, which is substantially negative to the expccted reversal of $-88 \mathrm{mV}$. In the remaining cells, reversal potentials could not be obtained in the voltage range tested. However, the slow spike afterhyperpolarization, a calcium-activated $\mathrm{K}^{+}$conductance (Andrade and Aghajanian, 1984), reversed between -85 and $-90 \mathrm{mV}$ in the same cells (as measured by the analysis of tail currents).

Further evidence for the existence of two components of the opioid-induced outward current comes from the finding that sodium substitution with either Tris or choline reversibly and reproducibly shifted the reversal potential of the opiate response closer to the potassium reversal potential. Conceivably, the shift in reversal potential could be due to an improved space clamp resulting from the decrease in input conductance that occurs following sodium substitution. However, the shift in reversal was also accompanied by a decrease in the amplitude of the met-ENK-induced outward current. If the cxtrcmely negative reversal potentials of the opiate response recorded under control conditions were primarily due to action of opiates on potassium channels at electrotonically distant parts of the cell, then a lengthening of the space constant (as occurs after sodium substitution) should enhance the opiate-induced outward current and not reduce it by half. Thus, an improved space clamp has been shown to enhance a voltage-sensitive chloride current in hippocampal pyramidal cells, presumably by enhancing passive propagation of the current back to the recording site at the soma (Madison et al., 1986). Sodium substitution in LC neurons also did not alter the reversal potential of the spike afterhyperpolarization, which remained close to $E_{\mathrm{K}}$, indicating that the shift in reversal potential does not result from some generalized nonspecific action of $\mathrm{Na}^{+}$substitution.

Since the opiate response remaining after $\mathrm{Na}^{+}$substitution reversed ncar the $\mathrm{K}^{+}$reversal potential, we testcd the effect of external $\mathrm{Ba}^{2+}$, a potassium channel blocker, on the opiate response. In consonance with a previous report (North and Williams, 1985), $\mathrm{Ba}^{2+}(100 \mu \mathrm{M})$ reduced the amplitude of the opiateinduced outward current by about $40 \%$. Interestingly, it also shifted the reversal potential of the opiate response to more deeply negative potentials, suggesting that the opiate current remaining after $\mathrm{Ba}^{2+}$ was not primarily due to the opening of $\mathrm{K}^{+}$channels. The shift in reversal potential away from potassium reversal potential would be expected if the current remaining after $\mathrm{Ba}^{2+}$ was largely due to a second conductance, such as suppression of the sodium-dependent inward current. Thus, despite an improved space clamp after $\mathrm{Ba}^{2+}$ application (as a result of decreased input conductance), the remaining opiate response not only did not reverse at the $\mathrm{K}^{+}$reversal potential but moved away from it. In agreement with previous reports, $\mathrm{BaCl}_{2}$ also reversibly produccd an inward current with an increase in input resistance and it blocked inward rectification in all of the LC neurons tested (Williams et al., 1984, 1988; Osmanovic and Shefner, 1987). However, the negative shift in reversal potential of the opiate response following application of $\mathrm{Ba}^{2+}$ has not been reported previously. North and Williams (1985) obtained a maximal reduction of $50 \%$ in the opioid hyperpolarization following bath application of $300 \mu \mathrm{M}$ to $2 \mathrm{mM}$ $\mathrm{BaCl}_{2}$; however, they did not report the effect of these concentrations of $\mathrm{Ba}^{2+}$ on the reversal potential of the opiate response. Much lower concentrations of $\mathrm{Ba}^{2+}(1$ or $10 \mu \mathrm{M})$ produced no change in either the magnitude of the outward current at -60 $\mathrm{mV}$ or the reversal potential of the opiate response (Williams et al., 1988). Interestingly, even with $2 \mathrm{~mm} \mathrm{Ba}^{2+}$ the opiate responsc in LC ncurons was reduccd by only 50\% (North and Williams, 1985), whereas $100-300 \mu \mathrm{MBa}^{2+}$ reduces $\mathrm{GABA}_{\mathrm{B}}$ and dopamine $D_{2}$ responses by $>80 \%$ in the rat substantia nigra (Lacey et al., 1988). Both $\mathrm{GABA}_{\mathrm{B}}$ and $\mathrm{D}_{2}$ responses in the substantia nigra are due to the opening of the inward rectifier type of $\mathrm{K}^{+}$channels and reverse at $E_{\mathrm{K}}$.

In the present study, external $\mathrm{Ba}^{2+}$ or $\mathrm{Na}^{+}$substitution reduced the amplitude of the opiate response. However, despite improving the space clamp, they altered the reversal potential of the met-ENK-induced outward current in opposite directions, suggesting that these two treatments act on different conductances. This is confirmed by our observation that the opiate response was reduced to $\sim 20 \%$ of control values following combined treatment with external $\mathrm{Ba}^{2+}$ and $\mathrm{Na}^{+}$-substituted ACSF. This remaining current after the combined treatment may be due in part to residual sodium. The additivity of the two effects indicates that the two treatments diminish the opioid-induced outward current by different mechanisms, providing further evidence for the involvement of two conductances in the opiate response in LC neurons. There is precedence for $\mu$-opiate receptors having dual actions in the same cell. For example, in rat dorsal root ganglion neurons, opiates produce both excitatory and inhibitory effects (Crain and Shen, 1990). Opiates also inhibit calcium channels and open $\mathrm{K}^{+}$channels in the same sensory neuron (Schroeder et al., 1991).

The identity of the $\mathrm{Na}^{+}$-dependent conductance that is suppressed by opiates in LC neurons remains to be determined. A possible candidate could be the endogenous cAMP-dependent inward current that underlies pacemaking in LC neurons. Intracellular dialysis with cAMP-dependent protein kinase inhibitor hyperpolarizes LC neurons, as does sodium substitution (Alreja and Aghajanian, $1991 \mathrm{a}, \mathrm{b}$ ). Biochemically, opiates couple negatively to adenylate cyclase in various rcgions of the brain, such as the cerebellum, the striatum (Polastron et al., 1990; Van-Vliet et al., 1990), and the LC itself (Duman et al., 1988). The electrophysiological consequence of an inhibition of adenylate cyclase in LC neurons would be the suppression of the resting, endogenous cAMP-induced inward current in these neurons. Bath-applied 8-Br-cAMP (a membrane-permeable phosphodiesterase-resistant analog of cAMP) produces a depolarization in LC neurons that is fairly voltage independent between -60 and $-120 \mathrm{mV}$ (Wang and Aghajanian, 1987), making the cAMP current a likely candidate for the second component of the opiate response. In addition, $80 \%$ replacement of sodium in the ACSF by Tris or choline markedly attenuates the depolarizing effect of $8-\mathrm{Br}-\mathrm{cAMP}$, indicating that the current is carried at least in part by sodium (Wang and Aghajanian, 1987). We also have recently found that this current, which is insensitive to TTX and cobalt, reverses at $\sim-30 \mathrm{mV}$, consistent with a mixed $\mathrm{Na}^{+} / \mathrm{K}^{+}$cationic current (M. Alreja and G. K. Agha- 
janian, unpublished observations). A similar $\mathrm{Na}^{+}$-dependent, TTX-insensitive mixed cationic conductance is activated by cAMP in various invertebrate neurons. In gastropod neurons, both cAMP and cGMP activate an inward current that reverses at $-10 \mathrm{mV}$ (Connor and Hockberger, 1984). At present, we are investigating the possibility that the resting, endogenous CAMPdependent cationic conductance is identical with the $\mathrm{Na}^{+}$-dependent conductance that is suppressed by opiates in LC neurons.

\section{References}

Aghajanian GK, Rasmussen K (1989) Intracellular studies in the facial nucleus illustrating a simple new method for obtaining viable motoneurons in adult rat brain slices. Synapse 3:331-338.

Aghajanian GK, Wang YY (1986) Pertussis toxin blocks the outward currents evoked by opiate and $\alpha_{2}$-agonists in locus coeruleus neurons. Brain Res 371:390-394.

Aghajanian GK, Wang YY (1987) Common $\alpha_{2}$ - and opiate effector mechanisms in the locus coeruleus: intracellular studies in brain slices. Neuropharmacology 26:793-799.

Alreja M, Aghajanian GK (1991a) Activation of locus coeruleus (LC) neurons by cholera toxin: mediation by cAMP-dependent protein kinase. Neurosci Lett 134:113-117.

Alreja M, Aghajanian GK (1991b) Pacemaker activity of locus coeruleus neurons: whole-cell recordings in brain slices show dependence on cAMP and protein kinase A. Brain Res 556:339-343.

Andrade RA, Aghajanian GK (1984) Locus coeruleus activity in vitro: intrinsic regulation by a calcium-dependent potassium conductance but not $\alpha_{2}$-adrenoceptors. J Neurosci 4:161-170.

Brown JE, Muller KJ, Murray G (1971) Reversal potential for an electrophysiological event generated by conductance changes: mathematical analysis. Science 174:318.

Chiu TH, Chen TY, Ho CL, Chiang ST (1990) Electrophysiological effects of dermorphin on locus coeruleus neurons of rat. Neuropharmacology 29:747-755.

Connor JA, Hockberger P (1984) A novel membrane sodium current induced by injection of cyclic nucleotides into gastropod neurones. $\mathbf{J}$ Physiol (Lond) 354:139-162.

Crain SM, Shen K-F (1990) Opioids can evoke direct receptor-mediated excitatory effects on sensory neurons. Trends Pharmacol Sci 11:77-81.

Duman RS, Tallman JF, Nestler EI (1988) Acute and chronic opiateregulation of adenylate cyclase in brain: specific effects in locus coeruleus. J Pharmacol Exp Ther 246:1033-1039.

Egan TM, North RA (1986) Actions of acetylcholine and nicotine on rat locus coeruleus neurons in vitro. Neuroscience 19:565-571.
Lacey MG, Mercuri NB, North RA (1988) On the potassium conductance increase activated by $G A B A_{B}$ and dopamine $D_{2}$ receptors in rat substantia nigra neurones. J Physiol (Lond) 401:437-453.

Madison DV, Malenka RC, Nicoll RA (1986) Phorbol esters block a voltage-sensitive chloride current in hippocampal pyramidal cells. Nature 321:695-697.

Mayer ML, Westbrook GL (1983) A voltage-clamp analysis of inward (anomalous) rectification in mouse spinal sensory ganglion neurons. J Physiol (Lond) 340:19-45.

Nestler EJ (1992) Molecular mechanisms of drug addiction. J Neurosci 12:2439-2450.

North RA, Williams JT (1985) On the potassium conductance increased by opioids in rat locus coeruleus neurons. J Physiol (Lond) $364: 265-280$.

Osmanovic SS, Shefner SA (1987) Anomalous rectification in rat locus coeruleus neurons. Brain Res 417:161-166.

Parsons JE, Wallis RA, Panizzon KL, Wasterlain CG (1992) I ow sodium injury in the hippocampal slice is mediated through NMDA receptors. Brain Res 595:141-144.

Pepper CM, Henderson G (1980) Opiates and opioid peptides hyperpolarize locus coeruleus neurons in vitro. Science 209:394-396.

Polastron J, Boyer MJ, Quertermont Y, Thouvenot JP, Meunier JC, Jauzac P (1990) Mu opioid receptors and not kappa-opioid receptors are coupled to the adenylate cyclase in the cerebellum. $J$ Neurochem 54:562-570.

Schroeder JE, Fischbach PS, Zheng D, McCleskey EW (1991) Activation of $\mu$ opioid receptors inhibits transient high- and low-threshold $\mathrm{Ca}^{2+}$-currents, but spares a sustained current. Neuron 6:13-20.

Van-Vliet BJ, Mulder AH, Schoffelmeer AN (1990) Mu opioid receptors mediate the inhibitory effect of opioids on dopamine-sensitive adenylate cyclase in primary cultures of rat neostriatal neurons. $J$ Neurochem 55:1274-1280.

Wang YY, Aghajanian GK (1987) Excitation of locus coeruleus neurons by an adenosine $3^{\prime}, 5^{\prime}$-cyclic monophosphate-activated inward current: extracellular and intracellular studies in rat brain slices. Synapse 1:481-487.

Williams JT, Marshall KC (1987) Membrane properties and adrenergic responses in locus coeruleus neurons of young rats. J Neurosci 7:3687-3694.

Williams JT, Egan TM, North RA (1982) Enkephalin opens potassium channels on mammalian central neurons. Nature 299:74-77.

Williams JT, North RA, Shefner SA, Nishi S, Egan TM (1984) Membrane properties of rat locus coeruleus neurons. Neuroscience 13:137156.

Williams JT, North RA, Tokimasa T (1988) Inward rectification of resting and opiate-activated potassium currents in rat locus coeruleus neurons. J Neurosci 8:4299-4306. 